International Journal of Industrial Engineering and Management (IJIEM), Vol. 9 No 3, 2018, pp. 129-138 Available online at www.iim.ftn.uns.ac.rs/ijiem_journal.php

ISSN 2217-2661

http://doi.org/10.24867/JJIEM-2018-3-129

\title{
Minimizing and Balancing Ergonomic Risk of Workers of an Assembly Line by Job Rotation: a MINLP Model
}

\author{
Salvatore Digiesi \\ Polytechnic University of Bari, Department of Mechanics, Mathematics and Management, V. le Japigia 182, Italy, \\ salvatore.digiesi@poliba.it \\ Francesco Facchini \\ Polytechnic University of Bari, Department of Mechanics, Mathematics and Management, V. le Japigia 182, Italy, \\ francesco.facchini@poliba.it \\ Giorgio Mossa \\ Polytechnic University of Bari, Department of Mechanics, Mathematics and Management, V. le Japigia 182, Italy, \\ giorgio.mossa@poliba.it

\section{Giovanni Mummolo} \\ Polytechnic University of Bari, Department of Mechanics, Mathematics and Management, V. le Japigia 182, Italy, \\ giovanni.mummolo@poliba.it
}

Received (18.01.2018.); Revised (29.08.2018.); Accepted (03.09.2018.)

\begin{abstract}
In today's economic context the workforce is a crucial asset in manufacturing industries. The employee performance and productivity are affected by many factors related on one hand to the line efficiency and, on the other hand, to the well-being of the workers. On the basis of new technologies and driven by Industry 4.0 paradigms, the need of a high production rate cannot neglect the safeguarding of the workers. In case of repetitive manual tasks, workers are exposed to the risk of musculoskeletal disorders (MSDs), that can be reduced by applying ergonomics principles both in design (e.g. workstation design, equipment tools identification, etc.) and in operative phases (e.g. workload balance, tasks assignment, etc.).

In the operative phase, job rotation is one of the most widespread methods for alleviating physical fatigue and reducing the stress due to repetitive tasks. However, often, job rotation strategies fail due to the lack of systematic approach or effective management of rotation schedules, being very difficult to identify an effective job rotation schedule allowing maintaining the same productivity rate. The problem is of particular interest under the perspective of the workforce aging, a social European phenomenon which is also affecting production systems performance. Designing and scheduling of human-based assembly systems require a joint evaluation of production system performance and a good balancing of MSDs risk among workers.

The authors proposed a model for minimizing the exposure risk of workers involved in repetitive manual tasks, by balancing the human workloads and reducing the ergonomic risk within acceptable limits, for a given production target. Risk and its acceptability are evaluated using the RULA method, according to a mixed integer programming approach. Results shown the effectiveness of the model to identify the optimal job rotation schedules jointly achieving productivity and ergonomic risk goals.
\end{abstract}

Key words: Ergonomic risk balancing; UL-WMSDs; RULA; MINLP; productivity

\section{INTRODUCTION}

Most common musculoskeletal disorders (MSDs) are associated to repetitive and monotonous tasks due to manual activities that required arm and hand movements such as bending, straightening, gripping, holding, twisting, clenching and reaching. In ordinary condition these common movements are not particularly harmful, but high level of repetition, often associated to other factors (e.g. vibration, force of movements, temperature, etc.), makes them hazardous in particular work situations. The mechanisms through which injuries occur are not well known and considering the current state of knowledge the process can be likened to a black box. On the contrary, causes and effects are well known: the starting point is the overuse of a certain part of the body, to which many factors may contribute, and results are well-identified illnesses, such as tendonitis and bursitis. But what happens between the two phases, is not very clear and, in many cases, is strongly 
affected by individual's biological response [1]. According to the Agency for Safety and Health at Work [2], in the European Union, the work musculoskeletal disorders (WMSDs) are costing 3.3\% of GDP, which implies an annual cost of $€ 476$ billions and around 7 million of disability-adjusted life years (DALYs).

In Europe, despite the variety of efforts to control the ergonomic issues, based on engineering design changes, organizational modifications and workers training programs, the work-related musculoskeletal disorders represent the most common occupational diseases (fig. 1), and from 2007 to 2013, the percentage of people (from 15 to 64 years old) reporting a work-related health problem due to musculoskeletal disorders increased of $5 \%$.

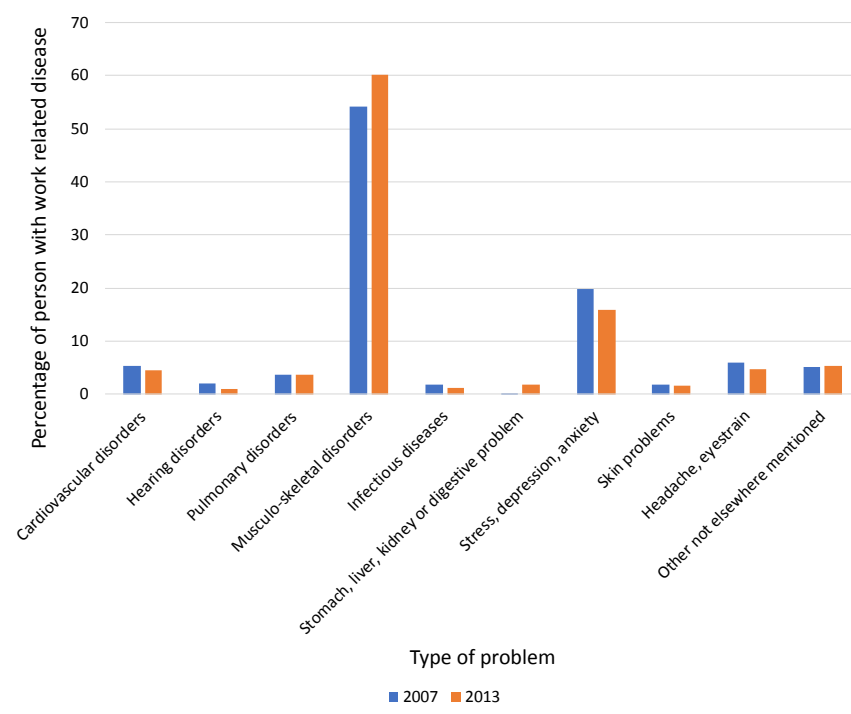

Figure 1. Persons reporting a work-related health problem in EU28 by type of problem

(source: https://ec.europa.eu/eurostat/web/lfs/data/database)

A worrying escalation of the WMSDs cases is highlighted in the last Health and Safety Executive report [3], and although a general downward trend of WMSDs cases from 2001 to 2010 has been registered in UK, in the last seven years the WMSDs cases have increased of $52 \%$ (fig. 2).

In this context, the introduction of new technologies represents a challenge for the national and international manufacturing industry since the technological change can improve the workers' well-being. According to this perspective, the new manufacturing strategies changes the industrial value chain, creating a new relationship between workers and production cycles, in order to enhance the cooperation man-machine under ergonomic perspective and defining the importance of the professional skills [4].

In current manufacturing context, the so-called Industry 4.0 (14.0) transformation is in progress. 14.0 represents a major opportunity for EU manufacturing companies. The innovations due to 14.0 make easier to analyse machine data, helping to enhance quality and avoid faults in the production process. The main goal of 14.0 is to "rethink" factories through the use of digital technologies, to reconsider the design approach, and to monitor the production process in real time and by cloud-computing. 14.0 can be defined as the development of the manufacturing technologies able to ensure higher levels of interconnectivity, leading to a greater communication between machine and decentralised /local data processing [5].

The enabling technologies introduced by 14.0, are based upon the 'Nine Pillars of Technological Advancement': Additive Manufacturing, Internet of Things, Cloud Computing, Cybersecurity, Big Data, Virtual/Augmented Reality, Simulation, Robotics and Horizontal/vertical system integration, each of them contributing to ensure the optimisation, integration, and automation of the production flow in order to improve the efficiency and effectiveness of the relationships between humans and machines. In European context, the 14.0 model is being defined on the basis of the industrial activities of the individual member states and on the intervention of the European Commission through the initiatives of Horizon 2020. The ambitious goal consists of increasing the European industrial competitiveness with targeted investments to the realization of smart factories.

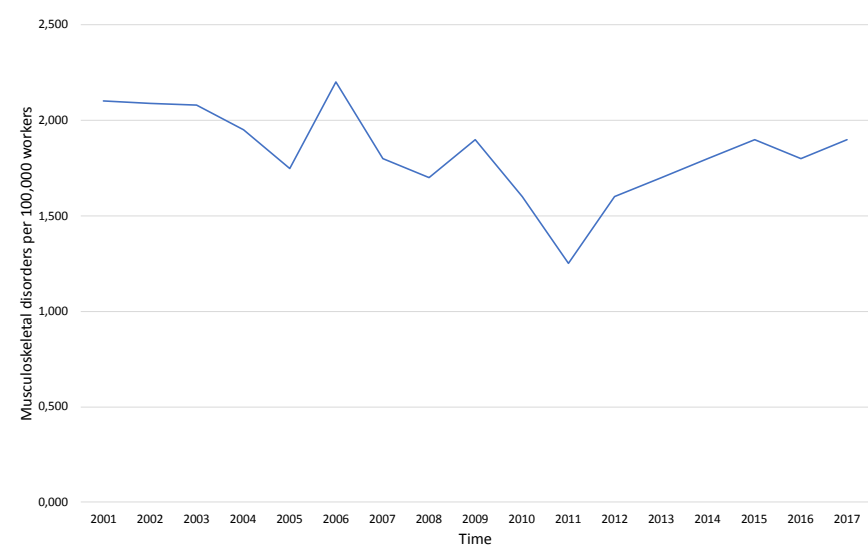

Figure 2. Musculoskeletal disorders per 100,000 workers in UK, from 2001 to 2017 (source: Health and Safety Executive WRMSDs Statistics in Great Britain 2017)

One of the major cornerstone to meet these challenges is the implementation of models based on the digital information and the communication technologies in order to introduce a dynamic production environment allowing, on one hand, to increase the industrial competitiveness and, on the other hand, to ensure the progress in well-being of the workers, especially for the ergonomic aspects related to the work environments and the equipment. In this perspective, the Virtual/Augmented Reality (VR), one of the current innovations introduced by 14.0, represents a new opportunity for investigating on the ergonomic issues and facilitating the human-machine interaction.

The main benefits gained from the simulation of the manual tasks during a work cycle can support the ergonomics evaluation according to two different approaches. In the first, the virtualization of the process can be adopted in preventive form for designing the workplaces and evaluating the required needs and identifying the realistic behaviours of the workers 
through a virtual anthropomorphic dummy that interacts with the environment. In the second, the VR can support the monitoring process through input devices allowing recording and tracking the movements of the workers, in order to evaluate, in real time, the ergonomic risk during the manufacturing cycle.

In the last decade there have been more than 270 papers published in major refereed international journals about the WMSDs and the loss of efficiency issue in human based production systems [6]. In most of them, the proposed approach for ensuring the workload smoothing, reducing the ergonomic risk, and increasing the productivity, is the job rotation. Currently, the problem of assigning jobs or tasks to workers, known as Job Rotation Scheduling Problem (JRSP), is the most widespread approach adopted in the case of repetitive assembly tasks [7].

Many models have been developed in order to identify the optimal solution for minimizing the risk exposure of the worker and for achieving a global balancing of the workload, using Integer Programming (IP), Mixed Integer Linear Programming (MILP), Mixed Integer Non Linear Programming (MINLP) model, Genetic Algorithm (GA), and many other methods.

Ayough et al. developed a multi-period IP model with the objective to minimize the total cost given by assignment and boring cost functions. Two search algorithms, GA and Imperialist Competitive Algorithm (ICA), are developed and adopted in order to solve and validate the algorithmic complexity in some industrial real cases and in different randomly produced test problems [8]. Otto and Scholl illustrated the JRSP in general terms and compared, by means of computational experiments, the performance of some heuristic procedures, under different aspects. In this way, the authors identified a fast and effective smoothing heuristic method that allows a good integration with computing devices and/or that can be adopted as a local re-optimization procedure [9].

Boenzi et al. presented the OCcupational Repetitive Action (OCRA) score method for the ergonomic risk assessment in case of infrequent job rotations.

The model allows to minimize the exposure risk of a single worker, adopting an algorithm for identifying, among all the feasible job rotations, the best solution in presence of a sub-group of operators with different ergonomic requirements [10] and with different skills [11]. A worker assignment job rotation problem with heterogeneous workers and jobs with different workload levels is presented by Moussavi et al, in which both productivity and ergonomic criteria are considered in the problem and a multi-objective mixedinteger mathematical model is proposed to implement an ergonomic job rotation in a production system.

The computational results shown the capability of the proposed model to optimize "daily workload" and ensuring an acceptable "production time" value [12]. A model for the activity schedules design of aged workers exposed to the risk of repetitive work is developed by Botti et al., where the approach adopted is based on a bi-objective perspective.
The first objective consists of reducing the ergonomic risk of repetitive tasks by varying the required movements and their intensity during the work shift. The second objective consists of assigning specified tasks to the workers considering their skills and abilities. The results shown that in most of the cases different solutions can be identified for pursuing each objective, therefore the choice of the preferred scheduling solution will be up to practitioners, on the basis of the predominant desired objective [13].

An innovative technique called Predetermined Motion Energy System, allowing to rapidly estimate the workers energy expenditure values, has been introduced in order to solving assembly line balancing problem considering time, cost, and ergonomic variables.

The application of the technique to a real case study provided useful information to the practitioners, in order to understand how the selection of the balancing solution rather than other factors impacts on the productivity of the system and on the ergonomic risk of the operators [14]. Mossa et. al developed a model which aims to find the optimal job rotation schedules in work environment characterized by low load manual tasks with a high frequency of repetition.

The model, based on a mixed integer programming, jointly allows maximizing the production rate and reducing and balancing human workloads and ergonomic risk within acceptable limits. Risk and its acceptability are evaluated using the OCRA score method [15].

Many others JRSP solved by means of a direct observation of the worker during his work shift are widely applied in industrial case studies. The effects of the human fatigue, evaluated on the base of an ergonomic approach, are investigated in order picking activities in logistic warehouses. Preliminary findings of the experimental study shown that in most cases there is a reversed $u$-shaped interrelation between physical fatigue and cognitive performance, whereas the ergonomic of the workplace appears to have a quite variable influence on fatigue effects [16,17].

A detailed review of the most common observational methods is proposed by Roman-Liu, where OWAS, revised NIOSH, OCRA, REBA, LUBA, and EAWS are compared [18].

In a smart factory, the well-being of the workers, in both the short and the long-term period, is one of the most important principles. Therefore an "ergonomic 4.0 " approach requires the assessment of repetitive tasks by means of an automated and continuous monitoring of the body position assumed by employs during the work shift. Manghisi et al. suggest an ergonomic evaluation using Kinect v2 sensor, in this case the ergonomic assessment is carried out by means of a computer processing and a skeleton tracking system.

The evaluation proposed does not require expensive devices and allows ensuring in real time the psychophysical wellbeing of worker consistently with paradigms introduced by the Fourth Industrial Revolution [19]. 
Currently in scientific literature there is a lack of studies providing solutions of the JRSP according to the adoption of the RULA, acronym of Rapid Upper Limb Assessment method [20], and the approaches allowing to jointly ensure a specify production rate and an acceptable ergonomic risk in manual assembly-line are not deep investigated.

Therefore, the purpose of this paper consists to develop a model for minimizing the exposure risk of workers involved in repetitive manual tasks for a given production target, by balancing the human workloads and reducing the ergonomic risk within acceptable limits. Risk and its acceptability are evaluated using the RULA method, according to a mixed integer programming approach.

The model can be adopted to solve the dual problem, that is to maximize the output of the production system meanwhile guaranteeing both a reduced musculoskeletal risk for the most exposed categories of employees and a balanced workload.

The paper is structured as follows: in Section 2 the rapid evaluation of the ergonomic risk is discussed; in Section 3 the proposed model is described; results obtained in case of a full-scale numerical experiment are in Section 4; finally, conclusions of this work are in Section 5.

\section{RAPID EVALUATION OF THE ERGONOMIC RISK FOR THE UPPER LIMB}

T A lot of methods and tools have been developed to help the managers and practitioners in estimating the incorrect postures and related activities for several industrial contexts.

The set of the most popular ergonomics evaluation methods includes OWAS, NIOSH lifting equation, RULA, REBA, and OCRA. Each of these observational methods has different features and adopts different key factors for ergonomics evaluations in the domains of posture, force, repetition (or frequency) of work, recovery time, dynamic use of force and full body risk evaluation as reported in table 1 .

Regardless to the specific method, the assessment results are typically defined as evaluation indices which are compared to threshold values. The tools are widely used in very different contexts and industries, but they are very time consuming and the scoring system is questionable, too [21]. Moreover, the observational methods, even if supported by multiple depth cameras, still require a heavy intervention by a field expert to estimate the required parameters (e.g. forces, loads, static/repetitive muscular activity etc.). Therefore, the ISO standard 11228-3:2007(E) [22] suggests the use of a simplified method in the early stage of the analysis and, only in case of critical conditions detected, standard suggests the adoption of the OCRA method for additional investigation.

The RULA (Rapid Upper Limb Assessment) method evaluates the exposure of individual workers to ergonomic risk factors associated with upper extremity MSD. The RULA ergonomic assessment tool considers biomechanical and postural load requirements of job on the neck, trunk and upper extremities. Usually several key risk factors must be considered when the risk is assessed for a given task, including force, posture, repetition (or frequency), duration of the task, and of the working day. So there are some factors that are not fully considered in the RULA method. Nevertheless these limits, it immediately gained a following because ergonomics practitioners were looking for a method that is fast, observational, able to perform the assessment in real time with not expensive equipment, and reliable.

At the same time, it needs trained skill in ergonomics in the evaluation phase of the results.

Table 1. Ergonomic risk evaluation methods, main features and factors considered

\begin{tabular}{|c|c|c|c|c|c|c|c|}
\hline Method & Features & Posture & Force & Frequen. & Recovery & Dynamic & Body \\
\hline $\begin{array}{l}\text { OWAS - Ovako Working Analysis } \\
\text { System (Karhu et al., 1977) [23] }\end{array}$ & $\begin{array}{l}\text { Work-related disorders on body portion. } \\
\text { No detail on upper limb. }\end{array}$ & Y & & Y & & Y & Y \\
\hline $\begin{array}{l}\text { NIOSH Manual lifting (NIOSH, } \\
\text { 1981) [24] }\end{array}$ & $\begin{array}{l}\text { Lifting equation. Definition of the RWL: } \\
\text { Recommended Weight Limit }\end{array}$ & & Y & Y & & & \\
\hline $\begin{array}{l}\text { RULA - Rapid Upper Limb } \\
\text { Assessment (McAtamney and } \\
\text { Corlett, 1993) [20] }\end{array}$ & $\begin{array}{l}\text { Rapid evaluation of upper body } \\
\text { members constraints }\end{array}$ & Y & Y & & & & \\
\hline $\begin{array}{l}\text { REBA - Rapid Entire Body } \\
\text { Assessment (Hignett and } \\
\text { McAtamney, 2000) [25] }\end{array}$ & Rapid evaluation of the whole body & Y & Y & & & & Y \\
\hline $\begin{array}{l}\text { OCRA - OCcupational Repetitive } \\
\text { Action (Colombini et al., 2002) [26] }\end{array}$ & $\begin{array}{l}\text { Upper limb repetitive movements } \\
\text { evaluation check list }\end{array}$ & Y & Y & Y & $\mathrm{Y}$ & & \\
\hline
\end{tabular}

The RULA method adopts a single page worksheet to assess and evaluate the ergonomic risk [20]. It consists of two sections for the risk assessment: section $A$ for the arm and wrist, and section $B$ for the neck and trunk.
After the data on posture, force, and repetition for each body region are collected and scored, a synthetic score (Table $\mathrm{C}$ ) representing the global level of MSD risk is calculated. 


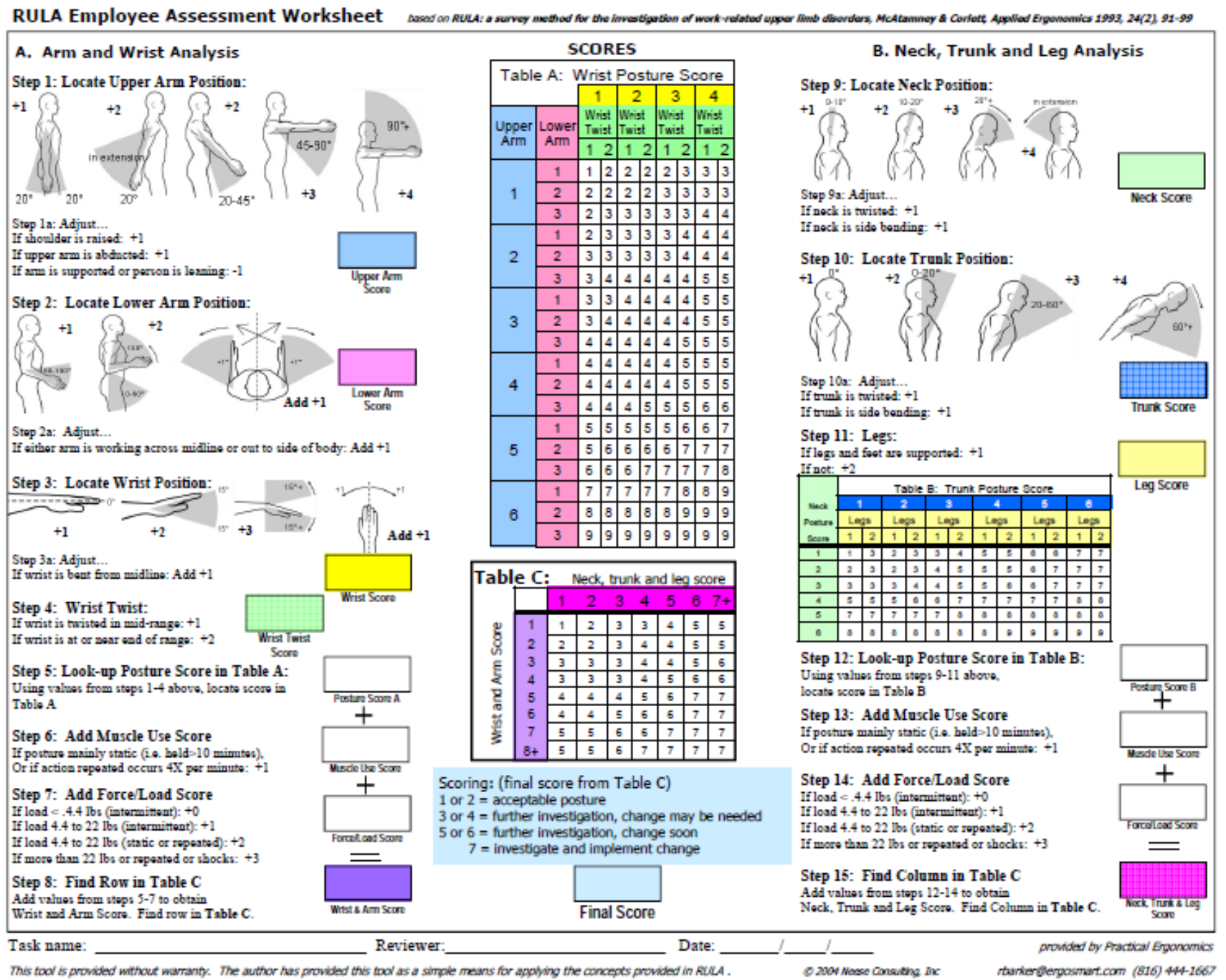

Figure 3. RULA risk asssesment method: the single page worksheet (source: McAtamney and Corlett, 1993)

The range limits of the RULA scores in table 2 estimate the different levels of MSD risk and the resulting requirements for action.

Table 2. RULA score, corresponding level of MSD risk, and requirements for action.

\begin{tabular}{cc}
\hline Score & Level of risk and Requirements for Action \\
\hline 1 or 2 & Negligible risk, no action required \\
3 or 4 & Low risk, changes may be required \\
5 or 6 & Medium risk, investigation and changes are required \\
7 & Very high risk, changes are required immediately. \\
\hline
\end{tabular}

\section{THE WORKER ASSIGNMENT MODEL}

A mixed integer nonlinear programming (MINLP) model is proposed for assigning the workforce to the WSs of a line balancing productivity and ergonomic goals. Hypothesis, symbols and assumptions adopted are in the following.

\subsection{Hypothesis and goal}

A single product manual assembly line is operated by differently aged and skilled workers. Workers are exposed to musculoskeletal disorders (MSDs) risk due to high frequency of repetition of manual tasks. Workstations can differ in the ergonomic risk (ER). The operating time of the assembly line during a given work shift is divided into a number of time slots. Workers can be assigned to workstations in each time slot. Net duration of time spent by a worker at each WS proportionally contributes to the individual ergonomic risk. The ER is measured by a timeweighted "overall" Rapid Upper Limb Assessment (RULA) method.

Every time a job rotation is performed at a WS during a time slot, a reduction in productivity is observed. The production time loss due to a job rotation of workers between any couple of work stations is considered constant over the work shift. 
Standard operation time of the workstations increases by a worker productivity factor with higher values for low skilled and aged workers. The worker productivity factor is constant over the work shift.

Given i) the desirable production output, ii) the manual operation times of workers at each WS, and iii) the individual ergonomic risk thresholds, the model identifies one or more optimal job rotation schedules that minimize the variability of the musculoskeletal risk exposure for the workforce assuring a balanced workload among workers.

\subsection{Symbols and definitions}

$m$ : number of workstations of the line;

$n$ : number of workers $(n>=m)$;

$K$ : number of time slots in a work shift;

$T_{k}$ : duration of the k-th time slot;

$T=\sum_{k=1}^{K} T_{k}: \quad$ line net operating time;

$t_{j}$ : standard operation time of $\mathrm{j}$-th workstation;

$k_{i j}$ : productivity factor of the $\mathrm{i}$-th worker at the $\mathrm{j}$-th workstation: the factor depends on worker skill and age;

$t_{r}$ : production time loss due to job rotation of a worker between a couple of WSs;

$x_{i, j, k}$ : assignment variable of worker (i) to WS (j) during the time slot $k$; it takes value 1 if the assignment is done and 0 otherwise; the initial condition $(k=0)$ is $x_{i, i, 0}=0, \forall i=1, \ldots, n ; \forall j=1, \ldots, m$;

$$
q_{i, j, k}=\frac{\left[T_{K}-t_{r}\left(x_{i, j, k}-x_{i, j, k-1}\right)\right]}{t_{j} \cdot k_{i, j}} x_{i, j, k}:
$$

number of items assembled by the $i$-th worker at the $j$ th workstation during the $\mathrm{k}$-th time slot;

$$
Q_{i, j}=\sum_{k=1}^{K} q_{i, j, k}:
$$

number of items assembled by the $\mathrm{i}$-th worker at the $\mathrm{j}$ th workstation in a work shift;

$$
P_{j}=\sum_{i=1}^{n} Q_{i, j}
$$

total production of the j-th workstation in a work shift;

$$
P_{L}=\operatorname{Min}_{\{j\}} P_{j}:
$$

total production of the line in a work shift;

$P_{L T}$ : production target of the line in a work shift;

$$
\overline{W T_{i, j}=\sum_{k=1}^{K} T_{K} \cdot x_{i, j, k}}
$$

working time of the $i$-th worker at the $j$-th workstation;

$R U L A_{J}:$ RULA index of the j-th workstation;

$$
R U L A_{i}=\sum_{i=1}^{m} R U L A_{j} \cdot \frac{W T_{i, j}}{T}:
$$

weighted RULA value of the $\mathrm{i}$-th worker during the work shift;

$R U L A_{i}^{\text {max }}$ : maximum admissible RULA value for the i-th operator;

$$
\bar{R}=\sum_{i=1}^{n} \frac{R U L A_{i}}{n}
$$

average RULA index of the $\mathrm{n}$ workers during the work shift;

$$
\sigma_{R}=\sqrt{\frac{1}{n} \sum_{i=1}^{n}\left(R U L A_{i}-\bar{R}\right)^{2}}:
$$

standard deviation of RULA;

$$
C V_{R}=\frac{\sigma_{R}}{\bar{R}}:
$$

coefficient of variation of the RULA $\mathrm{i}_{\text {. }}$

\subsection{Objective Function and Constraints}

Given a target level of production, the objective is the minimization of the coefficient of variation of the weighted RULA index of the whole workforce, thus ensuring the ergonomic workload balancing:

$$
\begin{gathered}
O . F .=\min _{\left\{x_{i . i . k}\right\}} C V_{R} \\
x_{i, i, k} \in\{0,1\}, \forall i, j, k
\end{gathered}
$$

subject to assignment, ergonomic, and production constraints.

$$
\begin{aligned}
& \text { - Assignment constraints } \\
& C_{1}: \sum_{i=1}^{n} x_{i, j, k}=1, \forall j=1, \ldots, m ; \forall k=1, \ldots, K
\end{aligned}
$$

each workstation can be operated by only one worker during each time slot.

$$
C_{2}: \sum_{i=1}^{m} x_{i, j, k}=1, \forall i=1, \ldots, n ; \forall k=1, \ldots, K
$$

each worker can be assigned only to one workstation during each time slot. 
- Ergonomic constraints

$$
C_{3}: R U L A \leq R U L A_{i}^{\max }, \forall i=1, \ldots n
$$

the specific weighted ergonomic risk of each worker cannot exceed his specific threshold.

\section{- Production constraint}

$$
C_{4}: P_{L} \geq P_{L T}
$$

the line should meet its production target.

\subsubsection{Dual problem formulation}

The problem can be re-formulated by maximizing the output of the system meanwhile guaranteeing both a reduced musculoskeletal risk for the most exposed categories of employees and a balanced workload:

$$
\begin{gathered}
\text { O.F. }=\max _{\left\{x_{i, i, k}\right\}} P_{L} \\
x_{i, i, k} \in\{0,1\}, \forall i, j, k
\end{gathered}
$$

subject to constraints $C_{1}, C_{2}, C_{3}$, and to the ergonomic risk balancing constraint

$$
C_{5}: C V_{R} \leq C V_{R}^{\max }
$$

\section{EXPERIMENTS AND DISCUSSION}

Numerical experiments have been carried out to test the model capability. Experiments refer to a production system of four manual assembly work stations (WSs) $(m=4)$. The assembly line is operated by four workers $(n=4)$. The duration of the work shift is 480 [min]. Each work shift consists of five working time slots $(K=5)$ (see Figure 4). Considering 4 planned rests, the net duration of one work shift is 405 [min].

$6: 00-14: 00$

\begin{tabular}{|l|c|c|c|c|c|c|c|c|c|}
$\begin{array}{l}k \\
T_{k} \\
{[\mathrm{~min}]}\end{array}$ & 80 & 15 & 80 & 15 & 95 & 30 & 80 & 15 & 70 \\
\hline
\end{tabular}

Figure 4. Operating time, time slots and rests durations [min]

Workers have different age and different skill. Starting from the standard operation time of each WSs (tj), by adopting different productivity factors (kij), the

\begin{tabular}{|c|c|c|c|c|c|c|}
\hline & & \multicolumn{4}{|c|}{ WS } \\
\hline & & $j$ & 1 & 2 & 3 & 4 \\
\hline & & $t_{j}[s]$ & 30 & 30 & 35 & 30 \\
\hline \multirow[t]{4}{*}{ Worker } & $i=1$ & \multirow{4}{*}{$t_{j} k_{i j}[s]$} & 30 & 30 & 38,5 & 33 \\
\hline & $i=2$ & & 30 & 30 & 35 & 30 \\
\hline & $i=3$ & & 36 & 36 & 38,5 & 33 \\
\hline & $i=4$ & & 36 & 36 & 42 & 33 \\
\hline
\end{tabular}

performance of each worker at each WS is obtained (Table 3).

Table 3. Standard operation time of the WSs and workers operation time [s]

RULA indices of each WS are in Table 4; the ergonomic risk is highly variable between the WKs; WS 4 is critical from the ergonomic point of view.

Table 4. RULA index of the j-th workstation

\begin{tabular}{rllll}
\hline & \multicolumn{5}{c}{$\boldsymbol{W S}$} \\
\hline $\boldsymbol{R} U L \boldsymbol{L} \boldsymbol{j}$ & 1 & 2 & 3 & 4 \\
\hline
\end{tabular}

Five scenarios have been developed and investigated. The first reference scenario (S1) is characterized by standard operation times with no productivity factor influence $\left(k_{i j}=1 ; \forall i, j=1, \ldots, 4\right)$ and no job-rotations. Assignments of workers to the WSs during the shift are in figure 5 .

In the scenario S2, the optimization model provides the workers' assignment by keeping the productivity to the maximum value $\left(k_{i j}=1 ; \forall i, j=1, \ldots, 4\right)$ and searching for a balanced ergonomic risk among workers. In this case a maximum admissible RULA value for the whole workforce is defined $\left(R U L A_{i}^{\max }<3\right)$, thus admitting only a negligible risk (see table 2).

The resulting job assignments are in figure 5. A comparison between $\mathrm{S} 1$ and $\mathrm{S} 2$ results (Table 5) outlines a more uniform workload in the operator's crew $\left(C V_{R}(\mathrm{~S} 1)=0,71\right.$ vs. $\left.C V_{R}(\mathrm{~S} 2)=0,07\right)$. Although there is a slight decrease in the line productivity $P_{L}(-$ $1,33 \%)$ a better balance of the WSs can be observed $\left(-10,7 \%\right.$ of $C V P_{j}$ with reference to $\left.S 1\right)$.

The effects of the productivity factors of the workers have been tested in scenario S3, where job-rotations are not allowed. The expected reduction in line productivity is of around $2,86 \%$ if compared with the initial reference case $\mathrm{S} 1$. No effects are observed to RULA values since no job rotation is considered.

Scenario S4 considers the hypothesis of workers rotation as well as the impact of the skill and productivity of the workers. In this case the best ergonomic performance is reached (CVR(S4) $=0,15$ vs. $\mathrm{CVR}(\mathrm{S} 3)=0,71$ ) with a small effect on line productivity (a reduction of $5,07 \%$ vs. a $2,86 \%$ reduction in the S3 compared to S1).

At the same time a good workload balance of the WSs can be observed $(-0,3 \%$ of $\mathrm{CV} \mathrm{Pj}$ vs an encrease of $9,7 \%$ in the S3 with reference to S1). 


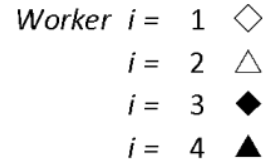

\begin{tabular}{|c|c|c|c|c|}
\hline$k$ & 12 & 3 & 4 & \\
\hline WS1 & $\triangle \boldsymbol{\Delta}$ & $\Delta$ & 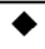 & \\
\hline WS2 & - & $\triangle$ & $\boldsymbol{\Delta}$ & \\
\hline WS3 & $\diamond \diamond$ & $\diamond$ & $\triangle$ & $\triangle$ \\
\hline WS4 & $\Delta \triangle$ & $>$ & $\diamond$ & $\diamond$ \\
\hline
\end{tabular}

(b)

\begin{tabular}{|c|c|c|c|c|c|}
\hline$k$ & 1 & 2 & 3 & 4 & 5 \\
\hline WS1 & $\diamond$ & $\boldsymbol{\Delta}$ & $\Delta$ & $\checkmark$ & $\nabla$ \\
\hline WS2 & $\boldsymbol{\Delta}$ & & $\diamond$ & $\diamond$ & \\
\hline WS3 & & 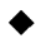 & $\triangle$ & $\triangle$ & $\triangle$ \\
\hline WS4 & $\triangle$ & $\triangle$ & & $\boldsymbol{\Delta}$ & $\boldsymbol{\Delta}$ \\
\hline
\end{tabular}

(d)

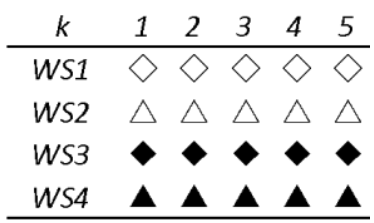

(a)

\begin{tabular}{cccccc}
$k$ & 1 & 2 & 3 & 4 & 5 \\
\hline WS1 & $\diamond \diamond$ & $\diamond$ & $\diamond$ \\
WS2 & $\diamond$ & $\diamond$ & $\diamond$ \\
WS3 & $\triangle$ & $\triangle$ & $\triangle$ & $\triangle$ \\
WS4 & $\mathbf{\Delta}$ & $\boldsymbol{\Delta}$ & $\boldsymbol{\Delta}$ & $\mathbf{\Delta}$ \\
\hline
\end{tabular}

(c)

\begin{tabular}{|c|c|c|c|c|c|}
\hline$k$ & 1 & 2 & 3 & & 5 \\
\hline WS1 & $v$ & 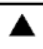 & $\boldsymbol{\Delta}$ & & \\
\hline WS2 & 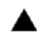 & & & & \\
\hline WS3 & & & $\triangle$ & & \\
\hline WS4 & $\triangle$ & & & & \\
\hline
\end{tabular}

(e)

Figure 5. Assignments of workers $(i=1, \ldots, 4)$ to WSs during the work shift $(k=1, \ldots, 5)-(a)$ Reference scenario $S 1$, (b) maximum productivity and job rotation scenario S2, (c) skill effect scenario S3, (d) skill effect and job rotation scenario S4, (e) low admissible risk scenario S5

Table 5. Coefficient of variation of the RULAi (CVR), and variation (\%) of CVR with reference to S1, Line Production (PL) [u/shift], variation (\%) of PL with reference to S1, Average WS production (Av Pj) [u/shift], variation (\%) of $A v \mathrm{Pj}$ with reference to $\mathrm{S} 1$, coefficient of variation of the total production of the $\mathrm{j}$-th workstation (CV Pj), and variation (\%) of CV Pj with reference to S1 - Scenario S1-S5

\begin{tabular}{ccccccccc}
\hline & $\boldsymbol{C V} \boldsymbol{V}_{\boldsymbol{R}}$ & $\boldsymbol{C} \boldsymbol{V}_{\boldsymbol{R}} \%$ & $\begin{array}{c}\boldsymbol{P}_{\boldsymbol{L}} \\
{[\mathrm{u} / \mathrm{shift}]}\end{array}$ & $\boldsymbol{P}_{\boldsymbol{L}} \%$ & $\begin{array}{c}\boldsymbol{A v} \boldsymbol{P}_{j} \\
{[\mathrm{u} / \mathrm{shift}]}\end{array}$ & $\boldsymbol{A v} \boldsymbol{P}_{j} \%$ & $\boldsymbol{C V} \boldsymbol{P}_{j}$ & $\boldsymbol{C V} \boldsymbol{P j} \%$ \\
\hline S1 & 0,71 & - & 684 & - & 771 & - & 0,075 & - \\
S2 & 0,07 & $-961 \%$ & 675 & $-1,33 \%$ & 751 & $-2,6 \%$ & 0,068 & $-10,7 \%$ \\
S3 & 0,71 & $0 \%$ & 665 & $-2,86 \%$ & 719 & $-7,3 \%$ & 0,083 & $9,7 \%$ \\
S4 & 0,15 & $-384 \%$ & 651 & $-5,07 \%$ & 707 & $-9,1 \%$ & 0,075 & $-0,3 \%$ \\
S5 & 0,28 & $-155 \%$ & 651 & $-5,07 \%$ & 701 & $-10,1 \%$ & 0,059 & $-27,7 \%$ \\
\hline
\end{tabular}

Finally, an additional scenario (S5) is considered for facing with a practical industrial situation: a smaller admissible RULA value has been considered for one worker ( $\mathrm{j}=4)$ who for age and/or skill consideration requires to be preserved for ergonomic workload. Int his case a maximun value of the ER is set (RULA4max = 1,5). The model provides a new solution which is compliant with all constraints showing a good capability in risk balancing among the workforce $(\mathrm{CVR}=0,28)$ while keeping unchanged the line production vs S4 ( $P L=651$ units/shift). Moreover in this scenario the greatest reduction in the variability of the production performance of the WSs has been achieved $(-27,7 \%$ with reference to $\mathrm{S} 1$ ).

\section{CONCLUSION}

Human dexterity in repetitive manual task with high frequency rises out relevant and conflicting issues: the need of preserving the worker well-being while meeting production target. An effective answer can be provided by a proper job rotation scheduling of workers involved in repetitive manual tasks.

In this paper, a model allowing to minimize the exposure risk of workers involved in repetitive manual tasks for a given production target, by balancing the human workloads and reducing the ergonomic risk within acceptable limits is proposed. Risk and its acceptability are evaluated using the RULA method, according to a mixed integer programming approach. The use of the model requires field investigations to assess model data; it is the case of the worker productivity parameter to consider age and skill of each worker.

However, the huge number of possible work environment situations limits reasonable hopes to standardize such a complex evaluation. To this concern, the model tool reveals of great usefulness in allowing sensitivity analysis and help production 
managers in decision making of proper job rotation schedules also in case of no or few field data available.

\section{ACKNOWLEDGMENTS}

The paper is the extended version of the work "A RULA-Based Optimization Model for Workers' Assignment to an Assembly Line" presented at the "XVII International Scientific Conference on Industrial Systems (IS'17), Novi Sad (Serbia) October $4-6$ 2017".

\section{REFERENCES}

[1] Ferri, G.M., Specchia, G., Mazza, P., Ingravallo, G., Intranuovo, G., et. al. (2017), "Risk of lymphoma subtypes by occupational exposure in Southern Italy", Journal of Occupational Medicine and Toxicology. Vol 12, No.1, 31

[2] Agency for Safety and Health at Work (2017), "Estimating the cost of work-related accidents and ill-health: An analysis of European data sources", available at https://osha.europa.eu/en/tools-and-

publications/publications/estimating-cost-work-related-accidentsand-ill-health-analysis/view (accessed: 19 September 2018).

[3] Health and Safety Executive (2017), "Work-related Musculoskeletal Disorders (WRMSDs) Statistics in Great Britain 2017', available

http://www.hse.gov.uk/statistics/causdis/musculoskeletal/msd.pd f (accessed: 19 September 2018).

[4] Luadante, E. (2017), "Industry 4.0, Innovation and Design. A new approach for ergonomic analysis in manufacturing system", The Design Journal, Vol. 20, No.1, pp. S2724-S2734.

[5] Ante, G., Facchini, F., Mossa, G., Digiesi, S. (2018), "Developing a key performance indicators tree for lean and smart production systems", IFAC-PapersOnLine, Vol. 51, No. 11, pp. 13-18.

[6] Battaia, O. and Dolgui, A. (2013), "A taxonomy of line balancing problems and their solution approaches", International Journal of Production Economics, Vol. 142, pp. 259-277.

[7] Paul, P., Kuijer, F.M., Visser Bart, K., Han, C.G. (1999), "Job rotation as a factor in reducing physical workload at a refuse collecting department”, Ergonomics, Vol. 42 (9), pp. 1167-1178.

[8] Ayough, A., Zandieh, M., and Farsijani H. (2012), "GA and ICA approaches to job rotation scheduling problem: considering employee's boredom", International Journal of Advanced Manufacturing Technology, Vol. 60, No.5, pp. 651-666.

[9] Otto, A. and Scholl, A. (2013), "Reducing ergonomic risks by job rotation scheduling”, OR Spectrum, Vol. 35 (3), pp. 711-733.

[10] Boenzi, F., Digiesi, S., Facchini, F., Mummolo, G. (2016), "Ergonomic improvement through job rotations in repetitive manual tasks in case of limited specialization and differentiated ergonomic requirements", IFAC-PapersOnLine Vol. 49, No.12, pp. 1667-1672.
[11] Boenzi, F., Mossa, G., Mummolo, G. Romano, V. A.( 2016), "Workforce Aging in Production Systems: Modeling and Performance Evaluation", Procedia Engineering, Vol. 100, pp. 1108-1115.

[12] Moussavi, S.E., Mahdjoub, M., Grunder, O. (2018), “A multiobjective programming approach to develop an ergonomic job rotation in a manufacturing system", IFAC-PapersOnLine, Vol. 51, No. 11, pp. 850-855.

[13] Botti, L., Mora, C., Calzavara, M., (2017), "Design of job rotation schedules managing the exposure to age-related risk factors", IFAC-PapersOnLine Vol. 50 (1), pp. 13993-13997.

[14] Battini, D., Delorme, X., Dolgui, A, Persona, A., Sgarbossa, F. (2016), "Ergonomics in assembly line balancing based on energy expenditure: a multi-objective model, International Journal of Production Research", Vol. 54, No. 3, pp. 824-845

[15] Mossa, G., Boenzi, F., Digiesi, S., Mummolo, G., Romano V.A., (2016), "Productivity and ergonomic risk in human based production systems: a job-rotation scheduling model', International Journal of Production Economics, Vol. 171, pp. 471-477.

[16] Winkelhaus, S., Sgarbossa, F., Calzavara, M., Grosse, E.H. (2018), "The effects of human fatigue on learning in order picking: an explorative experimental investigation", IFACPapersOnLine, Vol. 51, No. 11, pp. 832-837.

[17] Facchini, F., Mummolo, G., Mossa, G., Digiesi, S., Boenzi, F., Verriello, R., (2016), "Minimizing the carbon footprint of material handling equipment: Comparison of electric and LPG forklifts", Journal of Industrial Engineering and Management, Vol. 9, No. 5, pp. 1035-1046.

[18] Roman-Liu, D., (2014), "Comparison of concepts in easy-to-use methods for MSD risk assessment", Applied ergonomics, Vol. 45, pp. 420-427

[19] Manghisi, V.M., Uva, A.E., Fiorentino, M., Bevilacqua, V., Trotta, G. F., Monno, G., (2017), "Real time RULA assessment using Kinect v2 sensor", Applied Ergonomics, Vol. 65, pp. 481-491.

[20] McAtamney, L., and Nigel Corlett, E., (1993), "RULA: a survey method for the investigation of work-related upper limb disorders", Applied ergonomics, Vol. 24, pp. 91-99.

[21] Battini, D., Persona, A., Sgarbossa, F. (2014), "Innovative realtime system to integrate ergonomic evaluations into warehouse design and management", Computers and Industrial Engineering, Vol. 77, pp. 1-10.

[22] ISO, (2007), "System of Standards for Labor Safety. Ergonomics. Manual Handling - Part 3. Handling of Low Loads at High Frequency", International Organization for Standardization.

[23] Karhu, O., Kansi, P., Kuorinka, L. (1977), "Correcting working postures in industry: A practical method for analysis". Applied Ergonomics, Vol. 8, pp. 199-201.

[24] NIOSH (1981). "Work practices guide for manual lifting". NIOSH Technical Report $n^{\circ}$ 81-122, National Institute for Occupational Safety and Health. Cincinnaty. Ohio.

[25] Hignett, S., \& y McAtamney, L. (2000), "REBA: Rapid Entire Body Assessment". Applied Ergonomics, Vol. 31, 201-205.

[26] Colombini, D., Occhipinti, E., \& Grieco, A. (2002), "Risk assessment and management of repetitive movements and exertions of upper limbs", Amsterdam: Elsevier Science.

\title{
Minimiziranje i balansiranje ergonomskog rizika radnika montažne linije rotiranjem posla: Model MINLP
}

\author{
Salvatore Digiesi, Francesco Facchini, Giorgio Mossa, Giovanni Mummolo
}

Primljen (18.01.2018.); Recenziran (29.08.2018.); Prihvaćen (03.09.2018.)

\begin{abstract}
Apstrakt
$U$ današnjem ekonomskom kontekstu radna snaga je ključno sredstvo u proizvodnoj industriji. Na performanse i produktivnost zaposlenih utiču mnogi faktori vezani za efikasnost linije i dobrobit radnika. Na osnovu novih tehnologija i pod uticajem paradigme Industrije 4.0, potreba za visokom proizvodnom stopom ne može zanemariti zaštitu radnika. U slučaju ponavljajućih manuelnih zadataka, radnici su izloženi riziku od poremećaja mišićno-skeletnih organa (MSO), koji se mogu smanjiti primenom principa ergonomije kako u
\end{abstract}


dizajnu (npr. Dizajn radne stanice, identifikacija alata opreme, itd.), tako i u operativnim fazama (npr. balansiranje, dodeljivanje zadataka itd.). U operativnoj fazi, rotacija posla je jedna od najrasprostranjenijih metoda za ublažavanje fizičkog zamora i smanjenje stresa zbog ponavljajućih zadataka. Međutim, često strategije rotacije posla ne uspevaju zbog nedostatka sistematskog pristupa ili efikasnog upravljanja rokovima rotiranja, teško je identifikovati efikasan raspored rotacije posla koji omogućava održavanje iste stope produktivnosti. Problem je od posebnog interesa iz perspektive starenja radne snage, društvenog evropskog fenomena koji takođe utiče na performanse proizvodnih sistema. Projektovanje i raspoređivanje sistema za montažu zasnovanih na ljudima zahteva zajedničku procenu performansi proizvodnog sistema $i$ dobro uravnoteženje rizika MSO kod radnika. Autori su predložili model za minimiziranje rizika izloženosti radnika koji su uključeni u ponavljajuće manuelne zadatke, balansiranjem ljudskih radnih opterećenja $i$ smanjivanjem ergonomskog rizika u prihvatjjivim granicama, za određeni proizvodni cilj. Rizik i njegova prihvatljivost se procenjuju korišćenjem RULA metode, u skladu sa pristupom kombinovanog integrisanog programiranja. Rezultati pokazuju efektivnost modela kako bi se identifikovali optimalni raspored rotacije posla koji zajednički ostvaruju produktivnost i ergonomske ciljeve rizika.

Ključne reči: Ergonomsko balansiranje rizika; UL-WMSDs; RULA; MINLP; produktivnost 